\title{
HITEK ÉS TÉVHITEK A NÖVÉNYI ALAPÚ ÉTRENDRŐL EGY ONLINE KUTATÁS EREDMÉNYEI ALAPJÁN
}

\author{
$\longrightarrow$ hी \\ BELIEFS AND MISBELIEFS ABOUT PLANT-BASED DIET RELYING \\ ON THE RESULTS OF AN ONLINE RESEARCH
}

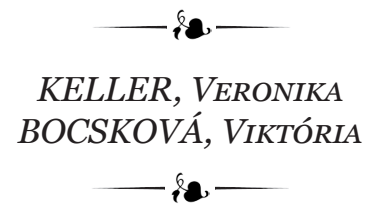

Széchenyi István Egyetem, Kautz Gyula Gazdaságtudományi Kar, Marketing és Menedzsment Tanszék (Széchenyi István University, Kautz Gyula Faculty of Economics, Department of Marketing and Management) H-9026 Győr, Egyetem tér 1. e-mail: kellerv@sze.hu

\begin{abstract}
Bl A main current trend is healthy lifestyle and the consumption of fruit and vegetables. The assessment of healthiness of plant-based diet is not so obvious either among the population or food experts. In an online survey the knowledge, beliefs and misbeliefs about plant-based diet were analysed among members and non-members of online social media lifestyles groups. All in all, it can be stated that there are no significant relationships and differences between knowledge, attitude and perception of members and non-members. Social media users are aware of the different types of plant-based diet (vegetarian, vegan) and the positive and negative psychological effects. The associations connected to plant-based diet are the following: healthy, environmentally friendly and expensive. Only a small segment of Hungarian people follow plant-based diet. At the same the diverse and everyday consumption of fruit and vegetables is essential because of health and sustainability issues. Due to conscious nutrition and more plant-based diet, people can contribute to the protection of their own health and the Earth.
\end{abstract}

KuLCSSZAVAK: növényi alapú étrend, online életmódcsoport, vegán, étrend, vegetarianizmus

JEL-Kód (JEL CODE): M31

DOI: https://doi.org/10.20494/TM/7/2/5

\section{BEVEZETÉS - INTRODUCTION}

Az ENSZ Egészségügyi Világszervezetének az egész világra kiterjedt kutatása rámutatott, hogy évente 2,7 millió ember halálában játszhat szerepet a nem elegendő zöldség- és gyümölcsfogyasztás. Napjaink gyümölcs-és zöldségfogyasztásának becsült szintje világszerte számottevően változik, a kevésbé fejlett orszá-
KEYwORDS: plant-based diet, online lifestyle group, vegan diet, vegetarianism

gokban kevesebb, mint 100 g/nap, Nyugat-Európában körülbelül $450 \mathrm{~g} / \mathrm{nap}$ (AUNE et al., 2017).

Az Eurostat 2017-es adatai alapján az Európai Unió 64 százaléka fogyaszt napi szinten gyümölcsöt, Olaszország (85\%), Portugália (81\%) és Spanyolország (77\%) álltak a lista élén. Az utolsó három helyen Litvánia (37\%), Bulgária (37\%) és Lettország (35\%) álltak, de 
Magyarország is csak a 25. helyre került a maga 40 százalékával. A zöldségfogyasztást vizsgálva is elmondható, hogy az uniós lakosság 64 százaléka fogyaszt napi szinten zöldséget. A lista első két helyén Belgium és Írország áll, itt a lakosság 84 százaléka eszik minden nap zöldséget. A harmadik helyen az olaszok (80\%) állnak, majd őket követik a portugálok (78\%). A legrosszabb eredménnyel Magyarország rendelkezik, a magyaroknak csupán a 30 százaléka eszik napi rendszerességgel zöldséget (EUROSTAT, 2017).

A 16 éves, vagy annál idősebb lakosság közel 40\%-a fogyaszt naponta valamilyen gyümölcsöt és valamivel több, mint 30\%-a zöldséget. A kutatásban résztvevők közül közel 12\% nem fogyaszt heti rendszerességgel gyümölcsöt, és $14 \%$ zöldséget sem. A zöldség- és gyümölcsfogyasztás gyakorisága szignifikáns kapcsolatban van a nemmel, iskolai végzettséggel és anyagi helyzettel: a nők, a magasabb iskolai végzettségűek és a magasabb jövedelmüek gyakrabban fogyasztanak zöldséget és gyümölcsöt. (KSH, 2018:3). A GfK Hungária Piackutató Kft. legújabb felmérései szerint a háztartások fogyasztásában a gyümölcs és zöldségek a 4. és 5. helyen szerepelnek. A gyümölcsök közül legtöbbet almából vesznek a magyarok, amit a banán, a dinnye, a narancs és a mandarin követ. A leggyakrabban vásárolt gyümölcs viszont a banán, az alma, illetve a citrom, a narancs és a szőlő. Zöldségekből paprikát vesznek hazánkban a leggyakrabban. Utána következik a paradicsom, a burgonya, a vöröshagyma és a sárgarépa. A mennyiséget tekintve azonban az első helyen a burgonya áll, és az első ötben szerepel még a paradicsom, a vöröshagyma, a paprika és a káposzta (GFK, 2020).

A tanulmány célja a növényi étrenddel kapcsolatos ismeretek feltérképezése, milyen hitek és tévhitek léteznek a növényi alapú étrenddel kapcsolatban, ezek mennyire térnek el az online életmódcsoport tagjai és nem tagjai között.

\section{SzAKIRODALMI ÖSSZEFOGLALÓ}

\section{- Theoretical Background}

A következő részben ismertetjük az élelmiszerfogyasztás trendjeit és tendenciáit, valamint a növényi alapú étrend alapelveit, előnyeit, hátrányait.

\section{1. Élelmiszer-fogyasztás trendjei, tendenciái - Trends and Tendencies of Food Consumption}

Az élelmiszerfogyasztás és a környezettudatosság összefüggéseinek vizsgálata napjaink egyik aktuális kutatási területe (KISS et al., 2019). A Törőcsik Mária vezette Trendinspiráció Kft. minden évben publikálja a következó évre előre jelzett aktuális trendeket. A 2019-es trendek közül kiemelnénk a „zöldség-sztárok” nevüt, amely a zöldségek felpozícionálásáról szól, azaz a növényi alapú étrend (plant based food) trend terjedéséról. A hús szerepét átvették a zöldségek, ami annak is köszönhető, hogy egyre több a kérdőjel a húsfogyasztást illetően, különösen, ami a környezetterhelést és a fenntarthatóságot jelenti (KISS et al., 2019). Így válik „a zöldség a köret státusból főfogássá.” Egyre nagyobb követő tábort szerez magának a szigorú veganizmus, amely mindenféle állati eredetű terméket elutasít (TÖRÖCSIK, 2019a és 2019b).

Minden trend megteremti a maga ellentrendjét (TÖRŐCSIK, 2011). Így a növényi alapú étrend ellenpólusaként megjelent a „mindent szabad" elv, amelynek a lényege a mértékletességen, az összetevők egyensúlyában és az étkezések rendszerességében jelenik meg (TÖRŐCSIK, 2014). Az Eon (2019) internetes magazin úgy írja le a ma egészségtudatosságra törekvő emberét, mint aki „távol tartja magát a szélsőségektől, természetes alapanyagokat keres, lehetőleg magának főz, mellőzi a cukrot és az előre csomagolt készételeket”. A TÉT Platform néhány évvel ezelőtt elvégzett kutatása 
szerint mindössze 2-2 százalék volt a vegán, illetve a vegetáriánus étrendet egészségesnek tartók száma. A magyarok jellemzően húskedvelők, nehezen mondanak le az állati eredetű élelmiszerekről, ugyanakkor a vegán életmód egyre nagyobb számú követővel rendelkezik (NAK, 2019).

\subsection{Növényi alapú étrend - Plant-Based Diet}

A növényi alapú étrend napjaink egyik divatos táplálkozási formája (TÖRŐCSIK, 2016), amelynek hatása az egészségre egyre több kutató figyelmét kelti fel. Valójában a növényi ala- pú étrendet már évszázadokkal ezelőtt is alkalmazták. A vegetarianizmus először Indiában, illetve az ókori görög világban jelent meg és mindkét kultúrában a vallási törekvések része volt. SZABÓ és munkatársai (2016:1860) úgy fogalmaznak, hogy „a növényi alapú étrend egy táplálkozási törekvés, amelynek célja az állati eredetü (húsok, húskészítmények, tej, tejtermékek, tojás), valamint az erősen feldolgozott élelmiszerek (lisztek, cukrok, olajok) háttérbe szorítása és a javarészt nyers, feldolgozatlan vagy minimálisan feldolgozott növényi eredetû élelmiszerek (magvak, diófélék, gabonafélék, hüvelyesek, gumósok, gyümölcsök, zöldségek) étrendbe történő beépítése."

\section{1. ÁBRA}

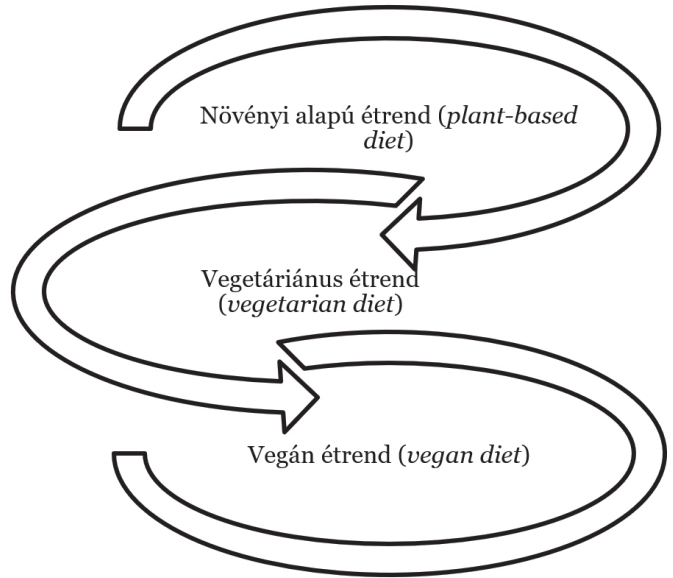

Forrás (Source): Saját szerkesztés (Own compilation)

\section{A növényi alapú étrend (Plant-Based Diet)}

A növényi alapú étrend a szigorú növényi (vegán) táplálkozástól egészen a szemivegetáriánusig terjed (1. ábra). Manapság a vegetarianizmus „már nem egyszerüen csak egy egészségtudatos táplálkozási irányzat, hanem egy holisztikus világnézet, amelynek képviselői zárt filozófiai, etikai-morális, környezetvédelmi és agrotechnológiai nézetrendszerben gondolkodnak; mások szocio-ökonomikus okokra hivatkoznak (BALOGH, 2017:181)”. A vegán életmódot követők teljes mértékben kizárják az állati eredetű származékok fogyasztását, így a húson kívül nem fogyasztanak tojást és tejtermékeket sem. Hazánkban 2017-ben érdekvédelmi egyesületük (Magyar Vegán Egyesület) alakult. A vegánság egy „erőszakmentes életmód követése”, amely az állatok bármilyen nemű kihasználása ellen foglal álláspontot. Ez mind az étkezésben (hús, tejtermékek, tojás, zselatin, méz stb. fogyasztásának elhagyása), mind az öltözködésben, szórakozásban megmutatkozik. A vegánok nem hordanak bőrcipőt, nem használnak olyan kozmetikai termékeket, amelyeket állatokon teszteltek. BALOGH (2017:188) a veganizmust a vegetarianizmus irányzatai közé sorolja. Emellett még számos más irányzat is létezik (BALOGH, 2017:187-188):

- Szemivegetarianizmus: az étrend részét képezi a baromfihús és a hal fogyasztása is.

- Ovovegetarianizmus: a növényi ételek mellett tojást is fogyasztanak.

- Ovo-lakto vegetarianizmus: a növényi 
élelmiszerek mellett tojást és tejtermékeket is fogyasztanak.

- Laktovegetarianizmus: a növényi ételek mellett az állati eredetű tejtermékeket is fogyasztanak.

- Peszko-vegetarianizmus: ahol a növényi ételek mellett halat is fogyasztanak.

- Nyers vegetarianizmus: hívei a vegetáriánus ételeket 75-100\%-ban nyersen fogyasztják.

A növényi alapú étrendet követők motivációit vizsgálva megállapítható, hogy leggyakrabban etikai, ökológiai, ökonómiai, politikai, állatvédelmi vagy spirituális, illetve egészségügyi okok miatt választják ezt az életmódot. Több vallási irányzat - a brahmanizmus, a judaizmus, a hinduizmus - is a húsmentes vagy javarészt húsmentes táplálkozást preferálja (SZABÓ et al., 2016).

Hazai kutatók is vizsgálták a növényi alapú étrendet hátráltató (VÉHA et al., 2019a) és támogató tényezőket (VÉHA et al., 2019b). VÉHA és munkatársai (2019b) szerint a növényi alapú étrend legfőbb előnye az egészséget pozitívan befolyásoló tényezőkkel, illetve a jól(l)étre és elégedettségre, életminőségre gyakorolt kedvező hatásokkal magyarázható. Ezenkívül az etikus környezeti előnyök között olyan szempontokat azonosítottak, mint a gazdasági erőforrások hatékonyabb kihasználása, a globális környezetszennyezés csökkenő hatása és az állatvédelem. Gazdasági szempontból a növényi alapú étrend előnye a fenntarthatósággal áll összefüggésben, hiszen jóval kisebb az ökológiai lábnyoma, mint a húsfogyasztásnak, vagyis a mindenevő étrendnek. Napjainkban az egyik jelentős ok, amiért az emberek növényi alapú étrendre váltanak át az a klímaváltozás megfékezése. A növényi alapú táplálkozás 2,5szer kevesebb karbon kibocsájtást jelent a hús alapú étrenddel szemben.

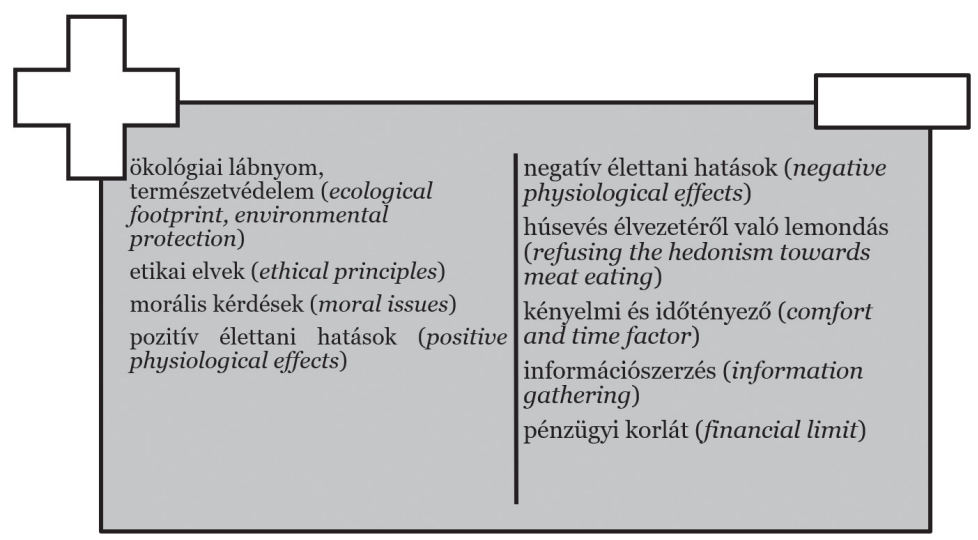

2. ÁBRA

FIG. 2

A növényi alapú étrend elónyei és hátrányai (Benefits and Risks of a Plant-Based Diet) Forrás (Source): Saját szerkesztés (Own compilation)

Másodsorban az etikai érvek szólnak a húsmentes étrend mellett (VÉHA et al., 2019b). Az egyik a jogokon alapuló, vagy deontológiai ${ }^{1}$ megközelítés, amelynek szakemberei szerint az állatok „az élet átélésének” képessége miatt önálló értékkel bírnak, ezért úgy kell tekinteni rájuk, mint akik önmagukban is célok, nem pedig egy cél eszközei. A másik megközelítés a haszonelvű, utilitarista vagy következményetikai (konzekvencialista), amelynek képviselői azzal érvelnek, hogy „minden érző lénynek meg kellene, hogy legyen legalább egy joga - a jog, hogy ne tulajdonként bánjanak vele”. Az etikai vegánok egyik jellemzője, hogy teljes mértékben elutasítják az állatok árucikké tételét. Továbbá nem használnak állati termékeket ruházkodásra, illatszernek, vagy bármi más célra, és próbálják elkerülni az állatokon tesztelt alapanyagokat is (BALOGH, 2017).

$\mathrm{Az}$ állattartás módja az etikai ellenvetések fő témáját alkotja. Az állatok túlzsúfolt istállókban és zárt térben kénytelenek élni, amelyek 
nem teszik lehetővé a természetes viselkedésük kifejezését. Az állatoktól megvonják a testmozgás lehetőségét, mivel azzal energiát égetnének el, ami anyagi veszteséghez vezetne. Továbbá természetellenes módon maximális hízásra kényszerítik az állatokat, ezáltal belső szervi megbetegedést, testi torzulást és szenvedést okozva. A vegetáriánus elvek az állatok levágásának egyetlen formáját sem tekintik emberségesnek.

A növényi alapú étrend számos jótékony, pozitív hatással lehet az egészségre és ezen keresztül az életminőségre, azonban ehhez nagyon felkészültnek kell lenni. A növényi táplálkozás általában kevesebb energiát, zsírt és ezáltal telített zsírsavat tartalmaz, ezáltal csökkenti a túlsúly, az elhízás és a szív- és érrendszeri betegségek kockázatát (SZABÓ et al., 2016).

A túlnyomórészt, vagy kizárólag növényi alapú táplálkozásnak megvannak a maga veszélyei is, mivel hiánybetegséget idézhet elő. Hiánypótlásra étrend-kiegészítőket vagy funkcionális élelmiszereket szükséges fogyasztani (SZAKÁLY, 2008). Mindenképpen javasolt a növényi alapú étkezésre való áttérés előtt dietetikusok segítségét kikérni. VÉHA és munkatársai (2019a) a növényi alapú étrendet hátráltató tényezők szakirodalmi feldolgozása során azt találták, hogy a negatív élettani hatásokon túl a húsevés élvezete és az arról való nehezebb lemondás; a kényelmi és időtényező, az információszerzés, a szociális korlátok és az ezzel járó negatív megkülönböztetés, valamint a pénzügyi korlátok gátolják a növényi alapú étrend terjedését (2. ábra).

A növényi alapú étrenddel kapcsolatban a közelmúltban több hazai kutatás (SZABÓ et al., 2016, VÉHA et al., 2019a és 2019b, illetve FEHÉR et al., 2020) készült. Főként a szakirodalmi hátteret ismertetik, illetve az étrend sajátosságait mutatják be. KRAUSE és munkatársai (2017) empirikus kutatás keretében vizsgálták az egyetemi hallgatók növényi étrendhez kapcsolódó ismereteit. FEHÉR és munkatársai (2020) szintetizáló tanulmányukban a tervezett magatartás modellt alapul véve egy koncepcionális modellt alkottak meg a növényi alapú étrendre történő váltás objektív támogató és gátló tényezőinek számbavételével, amit a jövőben empirikusan kívánnak tesztelni.

\section{ANYAg És Módszer - MATERIAL} AND METHOD

Jelen vizsgálat célja a növényi étrenddel kapcsolatos ismeretek feltérképezése az online életmódcsoport tagok, valamint nem tagok körében. Milyen hitek és tévhitek léteznek a növényi alapú étrenddel kapcsolatban, ezek menynyire térnek el az életmódcsoport tagjai és nem tagjai között. A táplálkozási trendek között szerepel a növényi alapú étrendhez szorosan kapcsolódó flexiariánus és a fenntartható étrend. Jelen kutatás ezen étrendek vizsgálatára nem vonatkozott.

Az alábbi kutatási kérdéseket fogalmaztunk meg:

1. Mi jellemző a zöldség-, és gyümölcsfogyasztásra az egyes csoportokban?

2. Milyen ismeretekkel rendelkeznek az egyes csoportok a vegetáriánus, a vegán, és a növényi alapú étrendről? Tervezik-e a növényi alapú étrend kipróbálást?

3. Milyen az attitűdjük a megkérdezetteknek a növényi alapú étrendről?

4. Milyen asszociációkat társítanak a növényi alapú étrendhez az egyes csoportok?

GÁL és munkatársai (2017) kutatási eredményei alapján különböző online életmódcsoportokat azonosítottak az egészségtudatos táplálkozás témakörével kapcsolatban ${ }^{2}$ netnográfiai módszer segítségével. A hozzászólásaikat, csoportbeli aktivitásukat tekintve különítették el az egyes csoporttagokat. Jelen kutatásunkban ilyen típusú elemzést nem végeztünk, csupán az életmódcsoporthoz való tartozás tényét vettük figyelembe. Előzetes feltételeink szerint az online életmódcsoportokat követőknek magasabb az érintettségük az egészség, egészséges táplálkozás témában, így valószínúleg pontosabb ismeretekkel rendelkeznek a növényi alapú étrendról.

A kvantitatív kutatás során főként metrikus skálákat használtunk, de átkódolással voltak olyan esetek, ahol nem metrikus mérési szintú változókat generáltunk.

- A zöldség- és gyümölcsfogyasztás gyakoriságát nominális skálán mértük, 5 kategória: naponta többször, naponta egyszer, 2-3 naponta, 4-5 naponta, nem

² (1) Kotnyeleskedők, (2) Szédelgók, (3) Kérdezősködők, (4) Némák, (5) Önjelölt szakértők, (6) Tényleges szakértők (7) Reklámozók 
fogyasztok zöldséget/gyümölcsöt heti rendszerességgel kategóriákkal.

- Gondolkozik azon, hogy növényi alapú étrendet kövessen? kérdés esetében 4 kategóriát adtunk meg: igen; nem; talán; igen, de csak rövid időre.

- Szelektív zárt kérdésekkel vizsgáltuk a vegetáriánus, a vegán és a növényi alapú étrend fő jellemzőit KRAUSE és munkatársai (2017) kutatásából kiindulva.

- 15 attitűdállítást fogalmaztunk meg a növényi étrenddel kapcsolatban, ami elsősorban a pozitív élettani hatásaival (segít megelőzni a krónikus betegségek kialakulását; könnyíti az emésztést; többletenergiát ad; környezetkímélőbb), és a negatív élettani hatásaival (nem juttatja elég proteinhez; ómega-3 zsírsavhoz a szervezetet), valamint az étkezési alapelveivel, az engedélyezett (ösztönzi az olajfogyasztást; a tejtermékek fogyasztását) és a tiltott élelmiszercsoportok (kizárja a feldolgozott élelmiszerek fogyasztását; nélkülözi vagy minimalizálja az állati eredetű termékek fogyasztását) fogyasztásával kapcsolatos ismereteket vizsgálta. A skála értékelése az 1: egyáltalán nem jellemző - 5: teljes mértékben jellemzó végpontokkal metrikus skálán került mérésre.

- A növényi alapú étrenddel kapcsolatos asszociációkat (10 darab ellentétpár) ötfokozatú szemantikus differenciálskálán (egyészséges - egészségtelen; veszélyes biztonságos; változatos - egyhangú, stb.) mértük.

- A szocio-demográfiai ismérvek (nem, életkor, lakhely, foglalkozás, családi állapot) nominális skálán mért változók.

A kutatási kérdések megválaszolásához a primer kutatási módszerek közül az egyszeri keresztmetszeti kutatást választottuk. A tervezett mintanagyság 400 fó volt, 200 fó online életmódcsoport tag, 200 fó nem tag. Az empirikus kutatás 2019 novemberében zajlott online önkitöltős kérdőív formájában. A lekérdezésben a szerzők vettek részt, akik egy hét alatt gyüjtötték be a válaszokat a Facebook közösségi oldal segítségével. A kutatók a saját isme- retségi körüket használták ki, illetve különböző életmódcsoportok tagjai között is megosztásra került a kérdőív, hogy a témában érdekelt felhasználók véleménye is bekerüljön a mintába. Végezetül 397 főt sikerült elérni, 45,6\%ban online életmódcsoportokat követőket és 54,4\%-ban pedig nem követőket. A válaszadók többsége tehát nem tagja semmilyen életmódcsoportnak, viszont akik igen, azok legnagyobb arányban Szafis csoportokat említettek („Éhezésmentes karcsúság Szafival”), valamint kedveltek még a különböző vegán csoportok („Ezt ettem ma vegán”), a gluténmentes étrenddel kapcsolatos csoportok és a különböző fitnesz csoportok („Kolly fitness blogja”).

$\mathrm{Az}$ online életmódcsoport tagok 83,4\%a nő, 16,6\%-a férfi, átlagéletkoruk 29,9 év, a szórás meglehetősen nagy 10,9 év, a módusz pedig 21 év. Az online életmódcsoportokhoz nem tartozók 82,9\%-a nő, 17,1\%-uk férfi. Átlagéletkoruk 32,9 év, a szórás 19 év, a módusz 19 és 23 év. A további demográfiai ismérvek alapján az egyes alminták megoszlását szemlélteti az 1. táblázat.

$\mathrm{Az}$ eredmények bemutatása előtt fontosnak tartjuk kiemelni, hogy a minta nem reprezentatív, nem veszi számba a teljes magyar lakosságot, a nők, a fiatal tanulók és a szellemi munkát végzők felülreprezántaltak a mintában. A kutatási kérdések megválaszolásához többváltozós statisztikai módszereket használtunk, kereszttábla elemzést és varianciaelemzést. Kereszttábla elemzéssel teszteltük a nominális változók közötti kapcsolatot, vagyis az első kettő kutatási kérdésre adott választ. Varianciaelemzéssel vizsgáltuk a növényi alapú étrenddel kapcsolatos attitűdöt (függő változó) és percepciót (függő változó) az online életmódcsoport tagok és nem tagok (független változó) között. A varianciaelemzés elvégzéséhez szükséges egyik feltétel a szóráshomogenitás, azaz a függő változó (attitűd, percepció) szórásának azonosnak kell lennie a független változó (online életmódcsoport tag, nem tag) minden szintjénél. Ennek tesztelésére a Levene-tesztet használtuk, amelynek nullhipotézise az, hogy a szórások egyenlők. Ez alapján minden esetben teljesül a szóráshomogenitás. 
A minta összetétele, \%

(The Demographic Composition of the Sample, \%)

\begin{tabular}{|c|c|c|c|c|c|c|c|c|c|}
\hline \multicolumn{5}{|c|}{$\begin{array}{c}\text { Online életmódcsoport tagja, \% } \\
\text { (Member of lifestyle group on social media, \%) } \\
181 \text { fó }(45,6 \%)\end{array}$} & \multicolumn{5}{|c|}{$\begin{array}{c}\text { Nem tagja online életmódcsoportnak, \% } \\
\text { (Non-member of lifestyle group on social media, } \\
\%) \\
216 \text { fö }(54,4 \%)\end{array}$} \\
\hline \multicolumn{10}{|c|}{ Életkor (Age) } \\
\hline $\begin{array}{l}\text { fiatal } \\
(18-24) \\
\text { (young) }\end{array}$ & $\begin{array}{l}\text { középkorú } \\
\text { (35-50) } \\
\text { (middle } \\
\text { aged) }\end{array}$ & $\begin{array}{c}50+ \\
\text { (senior) }\end{array}$ & & & $\begin{array}{l}\text { fiatal } \\
(18-24) \\
\text { (young) }\end{array}$ & $\begin{array}{l}\text { középkorú } \\
\text { (35-50) } \\
\text { (middle } \\
\text { aged) }\end{array}$ & $\begin{array}{c}50+ \\
\text { (senior) }\end{array}$ & & \\
\hline 70,7 & 23,2 & 6,1 & & & 58,8 & 34,3 & 6,9 & & \\
\hline \multicolumn{10}{|c|}{ Lakóhely (Residence) } \\
\hline $\begin{array}{c}\text { falu } \\
\text { (village) }\end{array}$ & $\begin{array}{l}\text { város } \\
\text { (town) }\end{array}$ & $\begin{array}{l}\text { megye- } \\
\text { székhely } \\
\text { (city with } \\
\text { county } \\
\text { rights) }\end{array}$ & $\begin{array}{l}\text { fóváros } \\
\text { (capital } \\
\text { city) }\end{array}$ & & $\begin{array}{c}\text { falu } \\
\text { (village) }\end{array}$ & $\begin{array}{l}\text { város } \\
\text { (town) }\end{array}$ & $\begin{array}{l}\text { megye- } \\
\text { székhely } \\
\text { (city with } \\
\text { county } \\
\text { rights) }\end{array}$ & $\begin{array}{l}\text { fóváros } \\
\text { (capital } \\
\text { city) }\end{array}$ & \\
\hline 27,1 & 37,0 & 23,8 & 12,2 & & 36,1 & 26,9 & 20,4 & 16,7 & \\
\hline \multicolumn{10}{|c|}{ Foglalkozás (Occupation) } \\
\hline $\begin{array}{c}\text { aktív } \\
\text { szellemi } \\
\text { (active } \\
\text { white-col- } \\
\text { lar job) }\end{array}$ & $\begin{array}{l}\text { aktív fizikai } \\
\text { (active } \\
\text { blue-collar } \\
\text { job) }\end{array}$ & $\begin{array}{c}\text { tanuló } \\
\text { (student) }\end{array}$ & $\begin{array}{l}\text { nyug- } \\
\text { díjas } \\
\text { (retired) }\end{array}$ & $\begin{array}{l}\text { munka- } \\
\text { nélküli } \\
\text { (unemp- } \\
\text { loyed) }\end{array}$ & $\begin{array}{l}\text { aktív } \\
\text { szellemi } \\
\text { (active } \\
\text { white- } \\
\text { collar } \\
\text { job) }\end{array}$ & $\begin{array}{l}\text { aktív fizikai } \\
\text { (active } \\
\text { blue-collar } \\
\text { job) }\end{array}$ & $\begin{array}{c}\text { tanuló } \\
\text { (student) }\end{array}$ & $\begin{array}{l}\text { nyug- } \\
\text { díjas } \\
\text { (retired) }\end{array}$ & $\begin{array}{c}\text { munka- } \\
\text { nélküli } \\
\text { (unemp- } \\
\text { loyed) }\end{array}$ \\
\hline 34,3 & 22,7 & 40,3 & 2,2 & 0,6 & 48,1 & 18,5 & 28,2 & 0,9 & 4,2 \\
\hline \multicolumn{10}{|c|}{ Családi állapot (Marital status) } \\
\hline $\begin{array}{l}\text { egye- } \\
\text { dülálló } \\
\text { (single) }\end{array}$ & $\begin{array}{c}\text { élettársi } \\
\text { kapcso- } \\
\text { latban élő } \\
\text { (in a re- } \\
\text { lationship) }\end{array}$ & $\begin{array}{l}\text { házas } \\
\text { (marri- } \\
\text { ed) }\end{array}$ & $\begin{array}{l}\text { családos } \\
\text { (family } \\
\text { with } \\
\text { children) }\end{array}$ & $\begin{array}{l}\text { elvált } \\
\text { (divor- } \\
\text { ced) }\end{array}$ & $\begin{array}{l}\text { egyedülál- } \\
\text { ló (single) }\end{array}$ & $\begin{array}{l}\text { élettársi } \\
\text { kapcso- } \\
\text { latban élő } \\
\text { (in a re- } \\
\text { lationship) }\end{array}$ & $\begin{array}{c}\text { házas } \\
\text { (married) }\end{array}$ & $\begin{array}{l}\text { családos } \\
\text { (family } \\
\text { with } \\
\text { children) }\end{array}$ & $\begin{array}{l}\text { elvált (di- } \\
\text { vorced) }\end{array}$ \\
\hline 33,1 & 35,4 & 13,8 & 14,4 & 3,3 & 30,1 & 29,6 & 25,0 & 10,6 & 4,6 \\
\hline
\end{tabular}

Forrás (Source): Saját kutatás (Own compilation) N=397

\section{EredménYeK - Results}

\subsection{Zöldség- és gyümölcsfogyasztás - Fruit and Vegetable Consumption}

A zöldségfogyasztás esetében közepesnél gyengébb (Cramer féle V értéke o,202) szignifikáns összefüggés $\left(\chi^{2}=16,13 ; p<0,001\right)$ észlelhető az életmódcsoport tagság alapján. Az online életmódcsoport tagok 40,9\%-a naponta többször, 26,5\%-a naponta egyszer, 23,2\%-a 2-3 napon- ta, 6,6\%-a 4-5 naponta fogyaszt zöldséget, és csupán 2,8\%-uk nem eszik heti rendszerességgel zöldséget. Aki nem tagja életmódcsoportnak. ott másként alakulnak az arányok: 22,7\% naponta többször, 33,3\% naponta egyszer, 28,2\% 2-3 naponta, 11,6\% 4-5 naponta, 4,2\% pedig nem fogyaszt napi rendszerességgel zöldséget.

A gyümölcsfogyasztás és az online csoporttagság között nincs szignifikáns összefüggés, viszont a csoporttagok ebben az esetben 
is gyakoribb fogyasztóknak számítanak. Az életmódcsoportokat követők 19,3\%-a naponta többször, 38,1\%-a naponta egyszer, 24,9\%-a 2-3 naponta, 8,8\%-a 4-5 naponta, valamint szintén ugyanennyi ritkábban, mint hetente eszik gyümölcsöt. Az online csoportokat nem követők 15,7\%-a naponta többször, 33,8\%-a naponta egyszer, 29,6\%-a 2-3 naponta, 13\%-a 4-5 naponta, 7,9\% nem fogyaszt heti rendszerességgel zöldséget.

\subsection{Vegetáriánus, vegán és növényi alapú étrend - Vegetarian, Vegan and Plant-Based Diet}

A következőkben azt elemeztük, hogy a válaszadók milyen ismeretekkel rendelkeznek a növényi alapú étrend különböző típusairól. A vegetáriánus étrend esetében közepesnél gyen- gébb (Cramer féle V értéke o,235) szignifikáns összefüggés $\left(X^{2}=21,91 ; p<0,001\right)$ mutatható ki az életmódcsoport tagság alapján. Az online életmódcsoporthoz tartozók 79\%-a úgy gondolja, hogy a vegetáriánus étrend a fehér és a vörös húsok, illetve a halak elutasítását, ugyanakkor az egyéb állati eredetű élelmiszerek, úgymint tojás és tejtermék fogyasztását jelenti. Ezzel az állítással a nem csoporttagok 57,4\%-a ért egyet. A valamilyen online életmód táborhoz tartozók 12,2\%-a véli úgy, hogy a húsfogyasztás nem, de a halfogyasztás megengedett a vegetáriánusok számára. Az online csoportokat nem követők esetében ez az arány nagyobb, 25\%-uk feltételezi ennek az elvnek az igazságát. Minden állati eredetű táplálék elutasítását az életmódcsoporttagok 7,7\%-a a nem tagok $13 \%$-a gondolja igaznak (2. táblázat).

A vegetáriánus étrend jellemzői, \% (The Attributes of Vegetarian Diet, \%) N=397

\begin{tabular}{|c|c|c|c|}
\hline & $\begin{array}{c}\text { Online } \\
\text { csoporttag } \\
\mathrm{N}=181 \\
\text { (Online } \\
\text { member, } \\
\text { N=181) }\end{array}$ & $\begin{array}{c}\text { Nem online } \\
\text { csoporttag } \\
\mathrm{N}=216 \\
\text { (Non-online } \\
\text { member, } \\
\mathrm{N}=216)\end{array}$ & $\begin{array}{l}\text { Összesen, } \\
\mathrm{N}=397 \\
(\text { Total, } \\
\mathrm{N}=397)\end{array}$ \\
\hline $\begin{array}{l}\text { Hús (fehér, vörös), hal, tejtermék és tojás elutasítása (Do not eat } \\
\text { (red, white) meat, fish, dariy, and eggs) }\end{array}$ & 7,7 & 13,0 & 10,6 \\
\hline $\begin{array}{l}\text { Hús (fehér, vörös, hal) elutasítása, viszont egyéb állati eredetű } \\
\text { élelmiszerek (tejtermék, tojás) fogyasztása (Do not eat any meat } \\
\text { (including red, white meat and fish), but do eat other animal } \\
\text { products including dairy and eggs) }\end{array}$ & 79,0 & 57,4 & 67,3 \\
\hline Állati eredetű termékek fogyasztása (Eat all animal products) & 1,1 & 4,6 & 3,0 \\
\hline $\begin{array}{l}\text { Hús (fehér, vörös) elutasítása, de hal fogyasztása (Do not eat red, } \\
\text { white meat, but do eat fish) }\end{array}$ & 12,2 & 25,0 & 19,1 \\
\hline
\end{tabular}

Forrás (Source): Saját kutatás (Own compilation)

Megjegyzés (Note): $\chi^{2}=21,91 ; \mathrm{p}=0,00$, Cramer féle $\mathrm{V}=0,235$

A vegán étrend esetében nincs statisztikailag szignifikáns összefüggés az ismeret és az online csoporttagság között. Az online életmódcsoporthoz tartozók 81,2\%-a, a nem csoporttagok 74,5\%-a gondolja úgy, hogy mindenféle állati eredetű termék, nemcsak a hús, hanem a tojás és a tejtermék elutasítását jelenti a vegán étrend. Viszonylag kevesen társítják ezt az étrendet a hús elutasításával, de a tojásés tejfogyasztás engedélyezésével (online csoporttag: 6,6\%; nem online csoporttag: 10,2\%), illetve a halfogyasztással (online csoporttag: 5,5\%; nem online csoporttag: $5,6 \%$ ).
Ahogy a szakirodalmi összefoglalóban jeleztük a növényi alapú étrendnek eltérő irányzatai léteznek, így a vegán és a vegetáriánus életmód, valamint annak különböző fajtái. Vizsgáltuk a növényi alapú étrend alapelveinek ismertségét is. A válaszadók többsége $(69,8 \%$ : online csoporttag 74\%-a; nem csoporttagok 66,2\%-a) feltételezi, hogy hasonló a vegán, vagy vegetáriánus étrendhez. Az online életmódtáborokat nem követők 31,9\%-a, az online csoportokhoz tartozók 25,4\%-a gondolja, úgy, hogy a növényi alapú étrend minimális húsfogyasztást és alapvetően húsmentes étrend követését jelenti. 
A halfogyasztást (o,3\%) és a tejtermék fogyasztását (1\%) alig jelölték.

A válaszadók csupán 21,9\%-a (online csoporttagok 23,8\%-a, nem csoporttagok 20,4\%a) gondolkodik azon, hogy növényi alapú étrendet kövessen. A többség $(56,4 \%)$ elutasítja ezt az étrendet, az életmódcsoport tagok 51,9\%-a és a nem tagok 60,2\%-a. A bizonytalanok aránya viszonylag alacsony, mindössze 14,4\% (az online csoporttagok 16\%-a, a nem csoporttagok 13\%-a). A TÉT Platform korábbi kutatása is megerősítette azt a tényt, hogy a magyar emberek jellemzően húsevők és nem lennének hajlandók növényi alapú étrendet követni. Nagyon kevesen $(7,3 \%)$ vannak azok, akik egy rövid időre, kúraszerúen tervezik a növényi alapú étrendre történő váltást, az életmódcsoportot követők 8,3\%-a és a nem követők 6,5\%-a.

\subsection{A növényi alapú étrenddel kapcsolatos attitüd - Attitude Towards Plant-Based Diet}

A növényi alapú étrenddel kapcsolatos attitüd 5 fokozatú Likert-skálán került felmérésre (3. táblázat). A válaszadók leginkább azzal értenek egyet, hogy ez a típusú étrend nélkülözi vagy minimalizálja az állati eredetű termékek fogyasztását, egészségügyileg előnyös, könnyíti az emésztést, csökkenti a telített (állati eredetü) zsírok fogyasztását és környezetkímélőbb más étrendhez képest. Közepes mértékben értenek egyet azokkal az állításokkal, hogy segít megelőzni a krónikus betegségek kialakulását, kizárja a feldolgozott élelmiszerek fogyasztását, valamint többletenergiát ad. Egyedül a nélkülözi vagy minimalizálja a tojásfogyasztást elv esetében van szignifikáns eltérés az online csoporttagok és nem csoporttagok véleménye között. A csoporttagok inkább egyetértenek ezzel az állítással, mint a nem csoporttagok. Közepes mértékü az egyetértés az összetett szénhidrátok fogyasztásának ösztönzése és az izomépítéshez megfelelő állítás esetében.

\subsection{A növényi alapú étrenddel kapcsolatos percepció - Perception about Plant-Based Diet}

Összességében kijelenthető, hogy a válaszadók tisztában vannak a növényi alapú étrend pozitív élettani hatásaival. Nincs statisztikailag szignifikáns különbség az online életmódcsoportokat követők és nem követők véleménye között. A kérdőívet kitöltők leginkább könynyen emészthetőnek, környezetkímélőnek, drágának, változatosnak ítélik meg a növényi alapú étrendet. Vannak olyan jellemzők, amivel kapcsolatban semleges álláspontot tanúsítottak a kutatásban résztvevők. Ugyanolyan mértékben gondolják veszélyesnek és biztonságosnak, unalmasnak és izgalmasnak, teljes értékünek vagy hiánytáplálkozásnak. Szintén a középérték körül mozog az átlag a divatos divatjamúlt, valamint az egyszerü és bonyolult ellentétpárok esetében (3. ábra).

\section{KÖVETKEZTETÉSEK ÉS JAVASLATOK - CONCLUSIONS AND PROPOSALS}

Jelen kutatásunkban legfóbb célkitűzésünk a növényi étrenddel kapcsolatos ismeretek feltérképezése volt az online életmódcsoport tagok, valamint nem tagok körében egy nagymintás kérdőíves megkérdezés segítségével. Az online életmódcsoport tagok jellemzően naponta fogyasztanak zöldséget és gyümölcsöt, illetve némiképp nagyobb gyakorisággal, mint a nem csoporttagok. A vegetáriánus étrendről az online életmódcsoporthoz tartozók pontosabb ismeretekkel rendelkeztek. A többség úgy gondolta, hogy vegetáriánus étrend a fehér és a vörös húsok, illetve a halak elutasítását, ugyanakkor az egyéb állati eredetű élelmiszerek, úgy mint tojás és tejtermék fogyasztását jelenti. A vegetarianizmusnak többféle irányzata létezik (BALOGH, 2017), így valószínúleg ebből adódtak a különböző engedélyezett és tiltott élelmiszerek fogyasztására vonatkozó ismeretek. 
A növényi alapú étrenddel kapcsolatos attitüd (The Attitude Towards Plant-Based Diet)

\begin{tabular}{|c|c|c|c|}
\hline $\begin{array}{l}\text { Állítások - A növényi alapú étrend... } \\
\text { (Statement - A plant-based diet...) }\end{array}$ & $\begin{array}{l}\text { Összesen } \\
\text { (Total) }\end{array}$ & $\begin{array}{l}\text { Csoporttag } \\
\text { (Member) }\end{array}$ & $\begin{array}{c}\text { Nem } \\
\text { csoporttag } \\
\text { (Non- } \\
\text { member) }\end{array}$ \\
\hline $\begin{array}{l}\text { nélkülözi vagy minimalizálja az állati eredetű termékek fogyasztását } \\
\text { (excludes or limits animal foods) }\end{array}$ & $3,98(1,33)$ & $3,95(1,34)$ & $4,01(1,33)$ \\
\hline $\begin{array}{l}\text { egészségügyileg előnyös lehet bizonyos betegségek esetén (is advantageous } \\
\text { in case of some illnesses) }\end{array}$ & $3,96(1,12)$ & $3,95(1,19)$ & $3,96(1,06)$ \\
\hline könnyíti az emésztést (makes digestion easier) & $3,86(1,18)$ & $3,91(1,19)$ & $3,82(1,17)$ \\
\hline $\begin{array}{l}\text { csökkenti a telített zsírok fogyasztását (reduces the } \\
\text { consumption of saturated fats) }\end{array}$ & $3,82(1,11)$ & $3,82(1,12)$ & $3,81(1,11)$ \\
\hline környezetkímélőbb (is more environmentally friendly) & $3,78(1,20)$ & $3,85(1,18)$ & $3,73(1,21)$ \\
\hline $\begin{array}{l}\text { segít megelőzni a krónikus betegségek kialakulását (helps in the prevention } \\
\text { of many chronic diseases) }\end{array}$ & $3,44(1,27)$ & $3,54(1,28)$ & $3,35(1,26)$ \\
\hline kizárja a feldolgozott élelmiszerek fogyasztását (avoids processed foods) & $3,39(1,38)$ & $3,54(1,41)$ & $3,27(1,35)$ \\
\hline többletenergiát ad (good for getting extra energy) & $3,33(1,30)$ & $3,41(1,35)$ & $3,27(1,27)$ \\
\hline $\begin{array}{l}\text { nélkülözi vagy minimalizálja a tojásfogyasztást } F=4,52 ; p<0,03 \\
\text { (limits or exludes eggs) }\end{array}$ & $3,27(1,34)$ & $3,43(1,30)$ & $3,14(1,36)$ \\
\hline $\begin{array}{l}\text { ösztönzi az összetett szénhidrátok fogyasztását (discourages complex } \\
\text { carbohydrates) }\end{array}$ & $3,04(1,23)$ & $3,07(1,27)$ & $3,02(1,19)$ \\
\hline izomépítéshez megfelelő (is perfect for muscle building) & $2,84(1,29)$ & $2,94(1,34)$ & $2,76(1,25)$ \\
\hline $\begin{array}{l}\text { nem juttatja elegendő ómega- } 3 \text { zsírsavhoz a szervezetet (makes an obstacle } \\
\text { to get Omega-3 fatty acids) }\end{array}$ & $2,51(1,23)$ & $2,45(1,26)$ & $2,56(1,20)$ \\
\hline nem juttatja elég proteinhez a szervezetet (cannot give enough protein) & $2,47(1,26)$ & $2,42(1,28)$ & $2,51(1,24)$ \\
\hline ösztönzi az olajfogyasztást (encourages oil consumption) & $2,38(1,16)$ & $2,33(1,21)$ & $2,42(1,13)$ \\
\hline ösztönzi a tejtermékek fogyasztását (encourages dairy consumption) & $1,95(1,14)$ & $2,04(1,21)$ & $1,88(1,06)$ \\
\hline
\end{tabular}

Forrás (Source): Saját kutatás (Own compilation)

Megjegyzés (Note): Az értékek az átlagot mutatják 1-től 5-ig terjedő skálán, a zárójelben szereplő értékek pedig a szórást (The values are means measdured on 5 point Likert scale and the values in brackets are standard deviation)

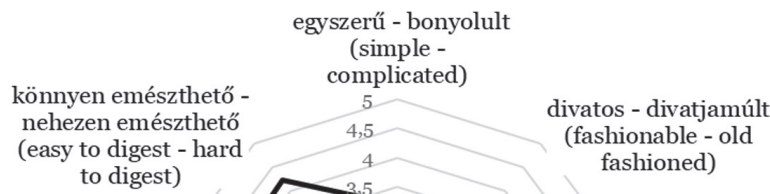

környezetkímélő környezetszennyező (environmentally friendly - unfriendly)

dárga - olcsó (expensive - cheap)

egészséges egészségtelen (healthy - unhealthy)

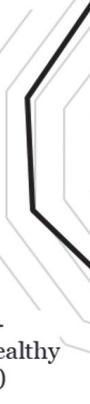

változatos - egyhangú

(variable - monotone)

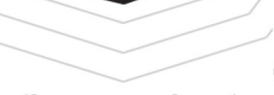

divatos - divatjamúlt

fashioned)

teljes értékü -

hiánytáplálkozás (full diet - lack diet)

unalmas - izgalmas

(boring - exciting)

veszélyes -

biztonságos

(dangerous - safe)

\section{3. ÁBRA}

\section{A növényi alapú étrenddel kapcsolatos percepciók (Perceptions of a Plant-Based Diet),}

Forrás (Source): Saját szerkesztés (Own compilation) 
A megkérdezettek szerint a vegán étrend mindenféle állati eredetű termék, nemcsak a hús, hanem a tojás és a tejtermék elutasítását jelenti. Viszonylag kevesen tervezik a növényi alapú étrend követését, illetve kipróbálását, ami alapvetően a húsfogyasztás élvezetével (VÉHA et al. 2019a, NAK, 2019) magyarázható. Az étrendet kipróbálni szándékozók is csupán átmeneti, időleges jelleggel tervezik az erre az étrendre való áttérést. Az attitűdök tekintetében elmondható, hogy pozitív a hozzáállás a megkérdezettek részéről, tisztában vannak az előnyökkel, a pozitív élettani hatásokkal (VÉHA et al., 2019a, SZABÓ et al. 2016, FEHÉR et al., 2020), illetve a táplálkozási irányzat alapelveivel. Asszociációk tekintetében olyan jelzőkkel, tulajdonságokkal, elvekkel társítják a növényi alapú étrendet, mint környezetkímélő, emésztést könnyítő, egészségügyileg előnyös, drága és változatos. Összességében megállapítható, hogy a közösségi média felhasználók, függetlenül attól, hogy tagjai vagy sem valamilyen életmódcsoportnak, tisztában vannak a növényi alapú étrend elveivel, jótékony hatásaival és esetleges negatívumaival (hiány(os) táplálkozás, veszélyes, bonyolult). Mindez magyarázható a minta demográfiai összetételével is, hiszen a mintában többségben voltak a fiatalok és a nők.

A növényi alapú étrend megítélése nem egyértelmű sem az emberek, sem a táplálkozásügyi szakértők körében. A magyar lakosság számára a hús fontos táplálék, kevesen lennének hajlandók róla lemondani (VÉHA et al., 2019a). Ugyanakkor a zöldség- és gyümölcsfogyasztás fokozása, változatos módon történő fogyasztása rendkívül fontos már kora gyerekkorban. Több olyan kormányzati intézkedés is született, amelyek jó kezdeményezések és ezzel a törekvéssel összhangban vannak, például iskolagyümölcs program, vagy az okostányérhoz kapcsolódó edukációs anyagok, okostányér. Emellett a vendéglátóipar is igyekszik a kínálatát az új táplálkozási trendeknek megfelelően kialakítani, és ennek keretében vegán ételekkel színesíteni a kínálatukat, vagy a vegán éttermeket is sorra nyitnak. A hazai piacon is megjelentek az influencerek, vloggerek, gasztrobloggerek, akik a vegán életmódot népszerűsítik, és a zöldségek változatos elkészítésére hívják fel a figyelmet. A kiskereskedelmi üzletek kommu- nikációjában is erőteljesen megjelenik a gyümölcs, zöldség termékkategória. Tudatos étkezéssel és a növényi alapú étrend gyakorlásával, legalábbis több zöldség és gyümölcs fogyasztásával jelentősen hozzájárulnánk nemcsak a saját egészségünk, hanem a Földünk megóvásához is.

A kutatás fó korlátai között említenénk meg a minta kis elemszámát és nem reprezentatív jellegét, hiszen főként fiatal nőket értünk el, akik feltételezhetőleg pontosabb ismeretekkel rendelkeznek a különböző életmódokról, étrendekről, így a növényi alapú étrendről is. Valószínúleg ez az oka annak, hogy nincs statisztikailag szignifikáns különbség az online életmódcsoporttagok és nem tagok ismerete, attitűdje és percepciója között. További korlátként említenénk meg, hogy az online felmérésben nem tértünk ki arra a kérdésre, hogy valójában követik-e a növényi alapú étrendet, vagy annak valamelyik irányzatát, csupán a jövőbeli tervekre vonatkozóan szerepelt kérdés.

A jövőben szeretnénk a kutatást kiterjeszteni a magyar lakosságra a téma aktualitása és gazdásági jelentősége miatt. Továbbá érdemes lenne a növényi alapú étrendet követők céljait, motivációit is feltérképezni, kezdetben kvalitatív kutatás formájában (fókuszcsoportos beszélgetés), késóbb pedig egy erre alapozott kvantitatív kutatás keretében. Érdekes lehet a növényi alapú étrenddel kapcsolatos prekoncepciók alaposabb vizsgálata, például valóban drága-e vagy sem. További kutatási terület lehet a másik étkezési véglet, a paleo és a ketogén, illetve a paleoketogén étrendekkel történó összevetés, elsősorban a környezeti, fenntarthatósági jellemzők figyelembevétele mellett.

\section{5. ÖSSZEFOGLALÁs - SUMMARY}

Az egészséges életmód terjedése napjaink egyik meghatározó trendje, ami egyben a zöldségek és gyümölcsök fogyasztását is jelenti. Azonban a növényi alapú étrend egészségességének megítélése nemcsak a lakosság számára, hanem a táplálkozásügyi szakértők számára sem egyértelmű. Online felmérés keretében vizsgáltuk a növényi étrenddel kapcsolatos ismereteket, hiteket és tévhiteket az online életmódcsoport tagok, valamint nem tagok körében. Összessé- 
gében megállapítható, hogy nincs szignifikáns eltérés az online életmódcsoport tagok és nem tagok ismerete, attitűdje és percepciója között. A közösségi média felhasználók tisztában vannak a növényi alapú étrend különböző fajtáival (vegetáriánus, vegán) és annak pozitív, illetve negatív élettani hatásaival. Olyan asszociációkat társítanak ehhez az étrendhez, mint egészséges, környezetkímélő és drága. A magyar lakosság viszonylag szúk rétege követ növényi alapú étrendet. Ugyanakkor a zöldségek és gyümölcsök változatos fogyasztása, mindennapi étkezésekbe történő beiktatása nemcsak egészségügyi, hanem fenntarthatósági szempontból is lényeges lenne. Tudatos étkezéssel és a növényi alapú étrend gyakorlásával jelentősen hozzájárulnánk nem csak a saját egészségünk, hanem a Földünk megóvásához is.

\section{KöSZÖNETNYILVÁNÍTÁS -}

\section{ACTKNOWLEDGEMENT}

A publikáció a Széchenyi István Egyetem által az EFOP 3.6.1-16-2016-00017 „Nemzetköziesítés, oktatói, kutatói és hallgatói utánpótlás megteremtése, a tudás és technológiai transzfer fejlesztése, mint az intelligens szakosodás eszközei a Széchenyi István Egyetemen" címú uniós projekt keretében készült.

\section{IRODALOMJEGYZÉK - REFERENCES}

Aune, D. - Giovannucci, E. - Boffetta, P. - Fadnes, Lars T. - Keum, N. - Norat, T. - Greenwood, D. C. - Riboli, E. - Vatten, L. J. - Tonstad, S.: Fruit and Vegetable Intake and the Risk of Cardiovascular Disease, Total Cancer and All-Cause Mortality - a Systematic Review and Dose-Response Meta-Analysis of Prospective Studies. International Journal of Epidemiology. 2017. 46 (3) 1029-1056. DOI: https://doi.org/10.1093/ije/dyw319

Balogh, S.: Az alternatív táplálkozás választható táplálékaink. Oriold és Társai Kiadó és Szolgáltató Kft., 2017.
EON: Tudatos életmód divatosan - 2019 egészségtrendjei. 2019. URL: https:// www.eon.hu/hu/blog/eletmod/tudatoseletmod-divatosan-2019-egeszsegtrendjei. html (Letöltés dátuma: 2019.12.06.)

Eurostat: Persons Eating Fruit, Vegetables or Salad by, Educational Attainment Level, Income Group, Most Frequent Activity Status, and Sex. 2017.

Fehér, A. - Gazdecki, M. - Véha, M. - Szakály, M. - Szakály, Z.: A Comprehensive Review of the Benefits of and the Barriers to the Switch to a PlantBased Diet, Sustainability, 2020. 12 (10) 1-18. 4136. DOI: https://doi.org/10.3390/ su12104136

Gál, T. - Soós, M. - Szakály, Z.: Egészségtudatos táplálkozással kapcsolatos fogyasztói insight-ok feltárása netnográfiával - esettanulmány. Vezetéstudomány. 2017. 48 (4) 4654. DOI: https://doi.org/10.14267/ VEZTUD.2017.04.07

GfK: Melyik zöldség és gyümölcs kerül a leggyakrabban a kosarunkba? 2020. URL: https://magyarmezogazdasag. hu/2020/o3/o5/melyik-zoldseges-gyumolcs-kerul-leggyakrabbankosarunkba (Letöltés dátuma: 2020.06.18.)

Kiss, V. - Dombi, M. - Szakály, Z.: $\mathrm{Az}$ egészség, a környezet és az étkezés kapcsolata - szakirodalmi áttekintés. Táplálkozásmarketing. 2019. 6 (1) 3-24. DOI: https://doi.org/10.20494/TM/6/1/1

Krause, A. - Williams, K. A.: Understanding and Adopting Plant-Based Nutrition: A Surves of Medical Providers. American Journal of Lifestyle Medicine. 2017. 6 (1) 312-318. DOI: https://doi. org/10.1177/1559827617703592

KSH: Egészségi állapot és egészségmegtartás, 2016-2017, 2017 Statisztikai Tükör, 2018 URL: https://www.ksh.hu/docs/hun/ xftp/stattukor/egeszsegallapot1617.pdf (Letöltés dátuma: 2020. 06. 18.) 
NAK: A vegetáriánus életmódon innen és túl. 2019. URL: http://nak.hu/en/ agazati-hirek/elelmiszeripar/150-gabonaedessegipar/99910-a-vegetarianuseletmodon-innen-es-tul (Letöltés dátuma: 2020.05.27.)

Szabó, Z. - Erdélyi, A. - Gubicskóné Kisbenedek, A. - Ungár, T. -Lászlóné Polyák, É. - Szekeresné Szabó Sz. - Kovács, R. E. - Raposa, L. B. - Figler, M.: A növényi alapú étrendről, Összefoglaló Közlemény. 2016. 157 (47) 1859-1865. DOI: https://doi. org/10.1556/650.2016.30594

Szakály, Z.: Trendek és tendenciák a funkcionális élelmiszerek piacán: Mit vár el a hazai fogyasztó? Élelmiszer, Táplálkozás és Marketing. 2008. 5 (2-3) 3-11.

Törőcsik, M.: Fogyasztói magatartás Insight, trendek, vásárlók. Akadémiai Kiadó, Budapest, 2011.

Törőcsik, M.: Az ételfogyasztás megatrend kapcsolódásai. Táplálkozásmarketing. 2014. 1 (1-2) 19-27. DOI: https://doi. org/10.20494/TM/1/1-2/2
Törőcsik, M.: A fogyasztói magatartás új tendenciái. Vezetéstudomány - Budapest Management Review. 2016. 47 (4) 19-25.

Törőcsik, M.: Aktuális trendek, 2019a. URL: https://www.trendinspiracio.hu/trendek (Letöltés dátuma: 2019.10.06.)

Törőcsik, M.: Food trendek. 2019b. URL: https://www.trendinspiracio.hu/ letoltesek/dokumentumok/food_trendek. pdf (Letöltés dátuma: 2019.12.06.)

Véha, M. - Szakály, Z. - Fehér, A.: A növényi alapú étrendet hátráltató tényezők rendszerezése - Szakirodalmi áttekintés. In: Egészségpiaci kutatások. 2019a. Publisher: Debreceni Egyetem, Gazdaságtudományi Kar

Véha, M. - Szakály, Z. - Fehér, A.: A növényi alapú étrendet támogató tényezők rendszerezése - Szakirodalmi áttekintés. In: Egészségpiaci kutatások. 2019b. Publisher: Debreceni Egyetem, Gazdaságtudományi Kar

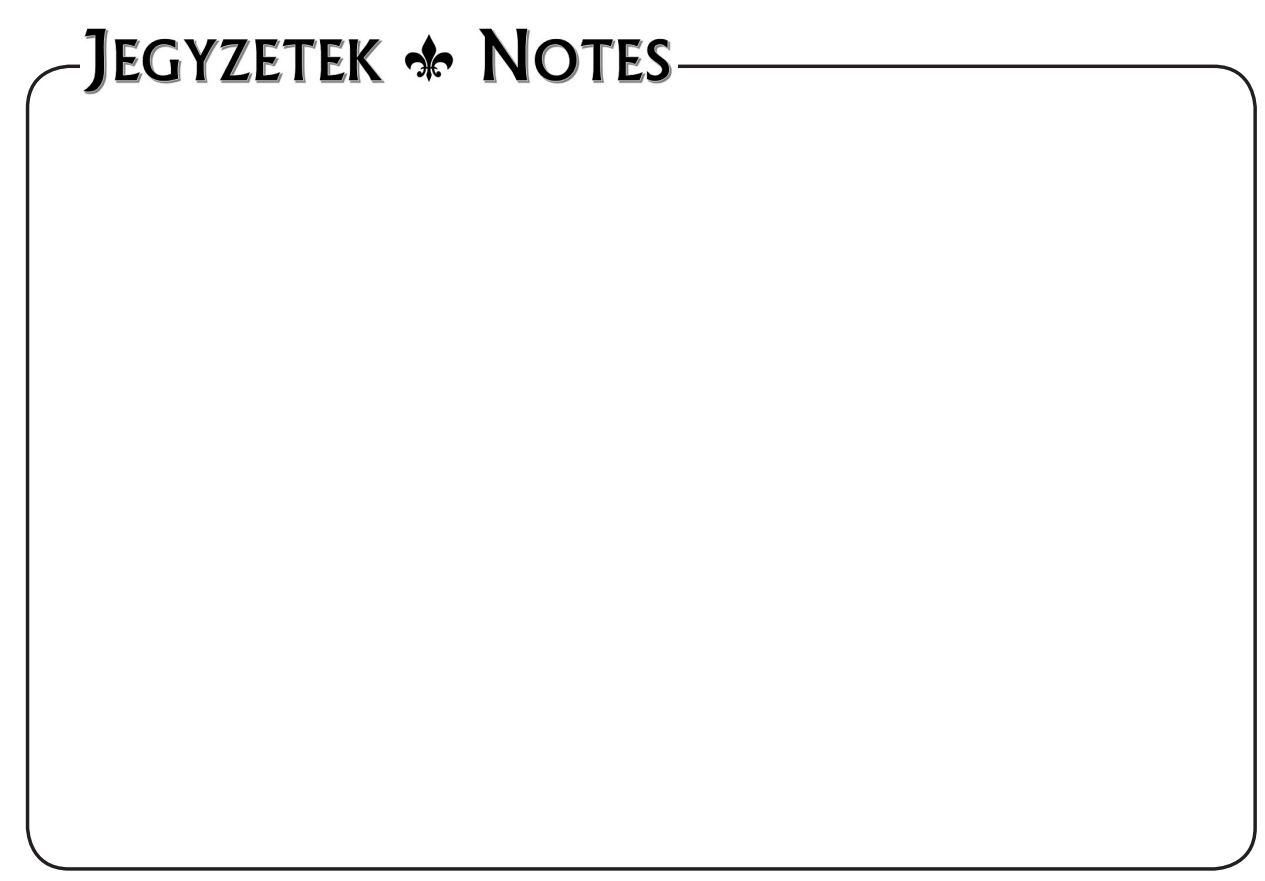

